\title{
A Study of the De-Mining Process in the Former War Zones in Sri Lanka (2009-2015)
}

\author{
OSANTHA NAYANAPRIYA THALPAWILA \\ DR
}

University of Kelaniya, Department of Political Science

e-mail: osantha@kln.ac.lk

Keywords civil war, demining, internally displaced persons, livelihood, resettlement, war zones

Abstract The 26 years of civil war in Sri Lanka had left destructive outcomes in the spheres of physical, economic as well as the social sectors of the country. Among them millions of land mines buried in former war zones is one of the biggest issue, because it could cause land mine accidents to the civilians. Therefore, it is an urgent task to implement a proper de-mining programme before resettling the Internally Displaced Persons (IDP). The aim of this paper is to look for the government initiatives on de-mining in the areas affected by the wars waged in the years 2009-2015. The primary data was collected from the interviews of resettled people in de-mining areas and other related officers who involved in resettling displaced persons. The secondary data was collected from the published reports by the related authorities. The government could successfully implement the de-mining programme with help of the Sri Lankan Army and other non-governmental organizations by covering $95 \%$ of the hazardous areas. A successful de-mining programme had facilitated the resettling of displaced persons while other economic initiatives had been set in motion in the former war zones.

\section{Badanie procesu rozminowywania w byłych strefach wojennych na Sri Lance (2009-2015)}

Słowa kluczowe wojna domowa, rozminowywanie, przesiedleńcy wewnętrzni, środki do życia, przesiedlenia, strefy wojny

Abstrakt

26 lat wojny domowej na Sri Lance pozostawiło destrukcyjne skutki w sferze fizycznej, gospodarczej i społecznej tego kraju. Problemem były i są miny lądowe zakopane w byłych strefach wojennych, ponieważ mogą one powodować wypadki z udziałem ludności cywilnej, dlatego pilnym zadaniem władz Sri Lanki jest wdrożenie odpowiedniego programu rozminowywania przed przesiedleniem ludności cywilnej. Celem artykułu jest przedstawienie rządowych inicjatyw dotyczących rozminowywania na obszarach dotkniętych wojnami z lat 2009-2015. Wtórnym materiałem badawczym wykorzystanym w niniejszym artykule są sprawozdania opublikowane przez władze Sri Lanki. Rząd wdrożył program rozminowywania z pomocą Armii Sri Lanki i innych organizacji rządowych, obejmując 95\% obszarów niebezpiecznych. Udany program rozminowywania ułatwił przesiedlenie wysiedleńców, podczas gdy na terenach dawnej wojny uruchomiono inne inicjatywy gospodarcze. 


\section{Introduction}

A successful resettlement process in the areas affected by conflict affected areas will have to be subject to several conditions related to the security of the resettled families and the future recovery of their livelihoods. Ensuring security is the most important matter before resettlement of the population that would be to their lives and livelihoods in the war affected areas. Although many theories have located de-mining under the security sector, some frameworks have included it in the resettlement sector, confirming it as a precondition for resettlement and for supporting the livelihoods of the Internally Displaced Persons (IDPs) and refugees. The 26 years of civil war in Sri Lanka had left destructive outcomes in the spheres of physical, economic as well as the social sectors of the country. The reports have revealed that there are millions of land mines buried in the areas affected by war causing land mine accidents to the civilians (Ministry of Economic Development, 2012). Therefore, it is an urgent task to implement a proper de-mining programme before resettling the IDP's and getting them to restart their livelihoods since several villages and public places were endangered by land mines and other explosives. Erin Mooney observed that special protection problems had arisen during resettlement as follows:

Landmines for instance, usually remain a significant threat long after conflict has ended.

Yet, compared to people who have remained in their home areas, displaced persons are at a distinct disadvantage in knowing where mines have been laid in their absence. ICRC statistics and other studies confirm that returning displaced persons and refugees comprise a disproportionate number of civilians injured or killed by land mines (Mooney, 2003, p. 12).

Likewise, it is very difficult to implement development projects in the war torn areas until a proper de-mining programme is carried out to confirm the safety of the area. The World Bank pointed out that de-mining is unique to post-conflict situations and essential for rehabilitation and recovery (Kreimer, Muscut, Elway, Arnold, 2000). The UN notion for peacebuilding, the Utstein model, the OECD model and the Miall et al. (1999) framework for post settlement peacebuilding discussed that mine removal action is an important part of the post-war reconstruction process in order to establish security in the post-war environment.

\section{Government Initiatives for De-mining}

De-mining for resettlement is not only an urgent and primary task for resettlement of the IDPs and refugees but is also a precondition for recovery and development of the conflict affected society. Generally, a war affects the lives and security of the people in several ways. The resettlement and development of the Northern and the Eastern provinces in Sri Lanka met with severe setbacks because of land mines scattered throughout the land. As mentioned above, de-mining is a primary task prior to resettlement and regarded as an early recovery step in the post-war period. Therefore, the government of Sri Lanka had to prepare a land mine free environment to continue the resettlement and recovery process. The Secretary to the Presidential Task Force 
(PTF) explained the intricate situation regarding de-mining in the Northern Province, where the protracted war was mainly fought:

Establishment of security was the first and priority task of our resettlement process. That was the most complex task we faced. At the end of the civil war, it had been estimated that over one million anti-tank and anti-personnel mines had been buried all over the battle areas in the North and the East. It was revealed that the Security forces as well as the LTTE had buried over one million land mines. The Army knew the locations of the most dangerous areas where they had buried the mines, but it was a very difficult task to locate the land mines of the LTTE because they had laid them everywhere. Anyway, we were finally able to successfully clear the land mines in the areas. ${ }^{1}$

It was estimated that 1.3 million land mines, both anti-personnel and anti-vehicle, as well as unexploded ordnances and improvised explosive devices were buried in the conflict affected areas. These mines rendered over 640 villages in the two provinces unsafe for free movement (Ministry of Economic Development, 2012). Further, the Northern Province was forced to abandon 101,827 hectares of paddy lands, 29,999 hectares of water bodies, $538 \mathrm{~km}$ of class A-roads, $1500 \mathrm{~km}$ of other roads, $263 \mathrm{~km}$ of railway lines and hundreds of public buildings such as schools, hospitals, railway stations, government offices, community halls etc. due to mine contamination (National Mine Action Committee, 2014).

Until the mine clearance was over the government could not carry out their resettlement projects in the North and the East. Consequently, the people could not return to their original habitats to continue their livelihoods. To make mine clearance a success, the government established the National Mine Action Coordinating Body, and this was followed by the setting up of the National Mine Action Centre with the assistance of the UNDP. The entire de-mining programme was managed by a National Security Committee for Mine Action established under the Ministry of Economic Development (Presidential task force for resettlement-Development, 2013). The Sri Lanka Army (SLA) produced the human resources under its Humanitarian De-mining Unit (HDU) with the assistance of international donors. ${ }^{2}$ Further, eight other local and international NGOs participated in the ground level operations with the HDU. ${ }^{3}$ The United Nations High Commissioner for Refugees (UNHCR) and International Organization for Migration (IOM) were among the major partners of the government de-mining programme. The government appreciated the role and assistance of the UNDP and other mine clearance organizations as follows:

The government established the national Mines Action Centre to coordinate and carry out the mine clearance. But we decided to get the assistance of the UNDP as well, because they

\footnotetext{
Interview with Mr. Divarathna, the Secretary to the PTF on 7 February, 2013 at Colombo.

2 Japan, Australia, European Union, Canada, Switzerland, U.K. and Norway funded the GOSL to undertake demining operations in Sri Lanka.

3 The other mine action operators are The HALO trust, Danish De-mining group, Foundation Suisse de De-minage, Mine Adversary group, Sarvatra, Horizon, Milinda Moragoda institute for people's empowerment and development assistance for social harmony.
} 
have much experience in de-mining procedures. So, the UNDP gave us all the knowhow and instructions for mine clearance. But mine clearance operations are still being continued by the Sri Lanka Army. We entrusted that task to them because they are familiar with all the areas in the battle field. Further, we asked 10 local as well as international organizations to assist us in this daunting and dangerous task. Altogether, there are around 2000 persons in the field engaged in this work. ${ }^{4}$

The de-mining operations were carried out with the help of modern machinery and technology, which were obtained from donor countries (Presidential Task Force for ResettlementDevelopment, 2013). The Sri Lanka Army and trained persons from the NGOs were involved in the mine action programme in hazardous areas.

The government had well understood the nature of the de-mining issue. In fact, the de-mining activity proved to be the most primary and urgent task in connection with the recovery of postwar society. Until an area was cleared, the government had no chance of implementing any resettlement programmes or development projects in that area. As the manual clearance method takes a long time, we decided to import mine clearance machines from Croatia. They were very sophisticated and efficient. ${ }^{5}$

By the end of March 2014, the government had made significant progress in de-mining large areas in the Northern and the Eastern provinces (See Table 1).

Table 1. Summary of the De-mining programme of the Government

\begin{tabular}{|l|l|}
\hline Confirmed hazardous areas in the North, the East and the North Central provinces & $2,064,796,286 \mathrm{sq} \mathrm{m}$ \\
\hline Fully cleared areas in the North and the East & $1,982,262,975 \mathrm{sq} \mathrm{m}$ \\
\hline Remaining areas to be cleared in the North and the East & $82,533,311 \mathrm{sq} \mathrm{m}$ \\
\hline Total expenditure incurred by GOSL & Rs 12,174 million \\
\hline Expenditure of other local and international partners & Rs 9,247 million \\
\hline
\end{tabular}

Source: Annual Report 2013, Ministry of Finance and Planning, Sri Lanka.

The HDU gave priority to the de-mining so that people could benefit by utilizing the land that had been rendered safe. In this respect the HDU had categorized the lands as follows: 1) areas required for the resettlement of people; 2) lands where people could restart their livelihood activities; 3) lands given to schools, hospitals, temples and churches; 4) lands with essential infrastructure in need of repairs, such as existing roads, electricity supply, water supply and irrigation systems; 5) hazardous areas within three kilometres of the villages, main roads and access roads; 6) lands required for development and construction of new infrastructure (Presidential Task Force for Resettlement-Development, 2013).

4 Interview with Mr. Divarathna the Secretary to the PTF on 7 February, 2013 at Colombo.

5 Interview with Mr. Divarathna the Secretary to the PTF on 7 February, 2013 at Colombo. 
This study observed that after the UNDP issued the clearance report for a particular area, the government could carry out the resettlement and reconstruction activities there.

The PTF will resettle the IDPs only in places where de-mining activities have been completed. Until the mine clearance reports are received from the UNDP, we never send people to those areas. Before they could leave the welfare camps, they had to attend the awareness programmes conducted by the authorities on mine risk education. ${ }^{6}$

The awareness programmes were conducted by the National Mine Action Centre and other partner NGOs that were involved in mine action projects. ${ }^{7}$ Awareness initiatives were intended to create greater public awareness on the land mine situation, and about mine action activities, direct and indirect impacts of anti-personnel land mine contamination, conveying a general idea about the indiscriminate effects of land mines and how the rest of the world set about tackling similar situations elsewhere (National Mine Action Committee, 2013).

The government reports point out that the mine clearance programme achieved a high level of success. In other words, the government was able to clear almost $96 \%$ of the landmines in the hazardous areas of the North and the East (see Figure 1). The following maps of mine affected areas (see figure 02) and the de-mining status in Northern Province show the progress made in de-mining (see figure 03) from 2009 to 2013 in the conflict affected areas of Sri Lanka.

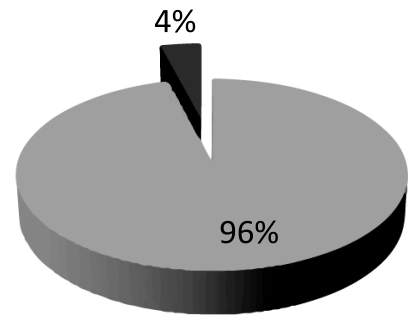

Totally Cleared

Areas

Remaining Areas to

be Cleared

Figure 1. De-mining Progress in the former war zones in Sri Lanka

6 Interview with Mr. Divarathna the Secretary to the PTF on 7 February, 2013 at Colombo.

7 The main objectives of the awareness programme was to create public awareness to prevent new casualties and reduce the casualty rate, strengthen victim assistance service, and to educate all stakeholders on these issues and get them to join the global mine ban community. http://www.slmac.gov.lk. 


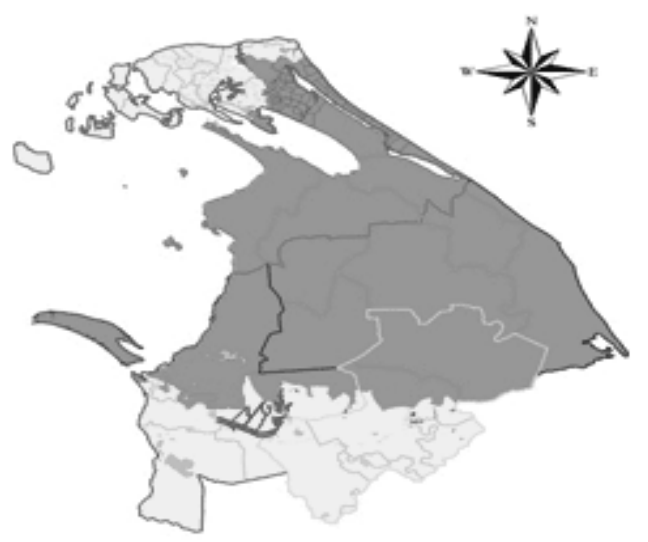

Legend

Mine Field Clearance Mine Field

Suspectas mine \& UXO contaiminant

Cleard using BAC

Figure 2. Mine affected areas in the Northern Province in 2009

Source: National Mine Action Programme, National Mine Action Committee, http://www.slnmac.gov.lk.

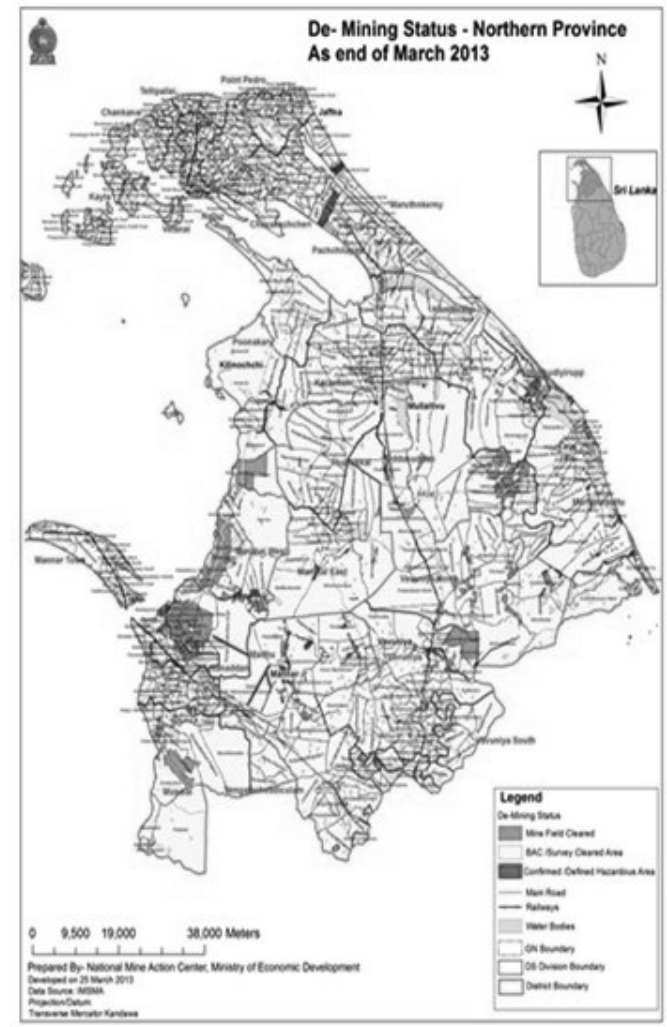

Figure 3. De-mining Status in the Northern Province at the end of March 2013.

Source: National Mine Action Programme, National Mine Action Committee, http://www.slnmac.gov.lk. 


\section{Achievements of the De-mining Process}

De-mining is an important, priority process that must be carried out before implementing the physical tasks of post-war reconstruction in the war affected zones. ${ }^{8}$ The newly established security then helps to restart the livelihoods of resettled persons and other development activities in the zones affected by war. This study accepts it as a core-task of resettlement and development of the zones affected by war in Sri Lanka. The following analysis also shows that the government's de-mining operations have been indispensable to facilitate the resettlement process and other development activities.

At the end of the war, the government of Sri Lanka faced a considerable problem in connection with the de-mining of the areas torn by war. The reports revealed that there were 640 villages in the two provinces that had been sowed with land mines during the period of war. In fact, the de-mining activities had been carried out in certain areas of the North and the East as early as 2002. But that work was not continued after the war escalated with the collapse of the ceasefire agreement between the parties in 2006. At the end of the war in 2009, the government established the 'National Mine Action Centre' in order to carry out an efficient de-mining programme in the Northern and Eastern provinces of the country. The government understood that an efficient de-mining programme would facilitate the resettlement of IDPs and reconstruction programmes that would be helpful to restart their livelihoods. In other words, the government could not carry out the resettlement and reconstruction process satisfactorily unless the de-mining programme was completed successfully. It was observed that the government had a formal and efficient programme on de-mining activities in all the districts of the North and the East. This programme was set up with the help of international and local bodies. The UNDP instructed and monitored the de-mining programme and all the novel technologies were used for field actions. The field operations were carried out by the Humanitarian Development Unit (HDU) of the Sri Lanka Army in collaboration with experienced international agencies who that had previous experience in successful de-mining operations throughout the world. For example, Danish De-mining Group (DDG) had worked in ten war torn countries of Africa, West Asia, South Asia and South East Asia during the last two decades and the organization was manned by experts. According to a spokesman of the organization:

DDG was fully operational in the Jaffna, Kilinochchi and Vauniya districts with a workforce of 14 manual de-mining teams, 4 survey teams, and 4 mechanical ground preparation units... The total number employed by DDG at that time was 470 national staff and 3 expatriate staff (Danish demining group, 2104).

The HALOU Trust group that engaged in de-mining work had carried out de-mining projects in 12 countries over the last decade. ${ }^{9}$ The National Mine Action Centre coordinated all these agencies and carried out the field actions. The mine action agencies showed keen interest in their

\footnotetext{
8 As successful as other de-mining programmes in war torn countries; see, Michael Helmick (2000) Humanitarian De-mining Policy, Pennsylvania: US Army War College.

9 HALOU Trust engaged in mine action in Afghanistan, Angola, Cambodia, Colombia, Georgia, Ivory Coast, Kosovo, Laos, Mozambique, Nagorno Karabakh, Somaliland, Sri Lanka, West Bank, and Zimbabwe.
} 
tasks. Technical field manager of Mine Action Committee, Mr. Biagio di Salvo explained their task as:

The contamination by mines is high, so we have to accurately check all the areas around the houses, around wells, around toilets, around big trees, around all those areas that can have some importance during a fighting scenario. We find mines even in the cemeteries. ${ }^{10}$

The reports and the field observations verified that the hard work and commitment of the mine action teams enabled them to reach their goal and report a successful outcome over the last four years. By the end of last year more than $95 \%$ of the hazardous areas had been cleared (Ministry of Finance and Planning in Sri Lanka, 2014) [see chart 1]. According to the reports approximately $82 \mathrm{sq} \mathrm{km}$ of jungles and mangroves, mostly in the former war zones still remain to be cleared (National Mine Action Centre, 2014).

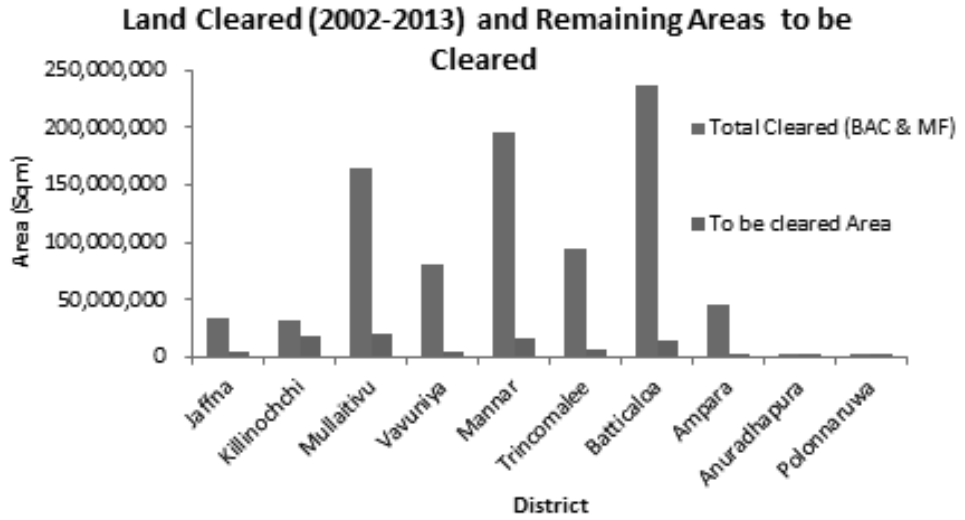

Chart 1. Land cleared of mines and remaining areas to be cleared Source: Sri Lanka Mine Action Programme, http://www.slmac.gov.lk.

Minister of Resettlement, Mr. Gunarathne Weerakoon stated:

Facilitating resettlement and solving livelihood issues are our twin priorities. De-mining has now reached its final phase and people can enjoy a complete return to normalcy then (IRIN, 2014).

Since de-mining has reached its final phase, the government expects that it will take another two years to clear the remaining areas. Sri Lanka military spokesman Brigadier Ruwan Wanigasooriya noted:

What remain to be cleared are the difficult stretches. This requires special skills and time, as they are de-mining manually, with minimum use of machines (IRIN, 2014).

10 “The women clearing Sri Lanka's mines" in BBC news. http://www.bbc.com (8.07.2014). 
Brigadier Wanigasooriya pointed out that some of the remaining areas are covered by thick jungles and so they have to be de-mined manually. Some of these areas were agricultural lands formerly, and they were contaminated with unexploded ordnance and land mines. According to military sources, the present stage of de-mining may go on for two to four years (IRIN, 2014). However, compared with de-mining projects in other war torn countries, the programme in Sri Lanka can be identified as a better achievement. ${ }^{11}$ It is noteworthy to mention that Sri Lanka could reach a successful stage within four years quantitatively as well as qualitatively. Because, according to the National Mine Action Centre, only 140 civilian landmine injuries were reported, with zero deaths over the past four years since 2009. The frequency of injuries had dramatically decreased since 2009 (see chart 2). ${ }^{12}$ The awareness programmes had contributed positively to the low number of casualties in Sri Lanka. The National Mine Action Centre pointed out that they had given priority to this matter and put much effort into the public awareness programmes (National Mine Action Committee, 2013).

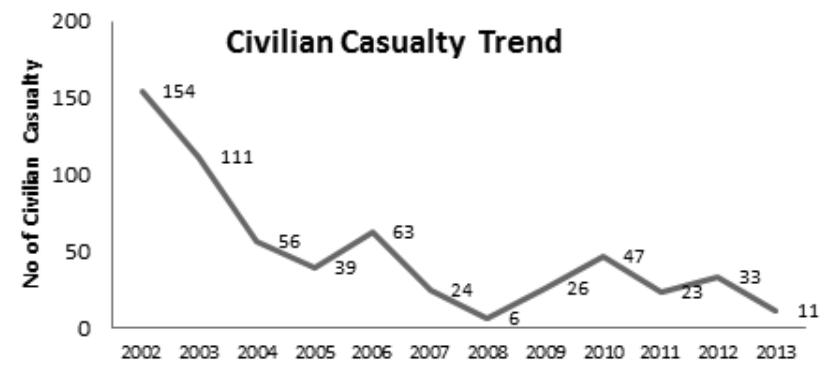

Chart 2. Civilian Casualty Trend

Source: Sri Lanka Mine Action Programme, http://www.slmac.gov.lk.

Sri Lanka Army officer, Brigadier Dananjaya Karunarathna pointed out:

We have increased the number of mine risk education lessons given to the civilians with support of UNICEF. With that the amount of civilian casualties drastically came down. ${ }^{13}$

The Secretary to the PTF stated:

Until the mine clearance reports are received from the UNDP, we never send people to those areas. Before they could leave the welfare camps, they had to attend the awareness programmes conducted by the authorities on mine risk education. ${ }^{14}$

\footnotetext{
${ }^{11}$ For instance, in Cambodia, the UNDP mine action project with the support of the international donors engaged in clearing the land mines from 2002. This project will have to continue at least for the next ten to fifteen years. See 'Cambodia: Demining transforms former battle ground into field hope' UNDP. http://www.undp.org (5.07.2014).

12 In Cambodia, the number of casualties from land mine explosions reported 4,300 in 1996.

13 “The women clearing Sri Lanka's mines" in BBC news. http://www.bbc.com (8.07.2014).

14 Interview with Mr. Divarathne, the Secretary to the PTF, on 7 February, 2014 in Colombo.
} 
Therefore, the objective of the awareness programme was successfully achieved by reducing the land mine casualties, and this provided a better, safer environment for returnees. Since the demining of the former conflicted areas was successful, the resettled families could now start their livelihood activities, especially farming and animal husbandry as usual. A villager of Nedunkerny stated that now they do not face any risks from land mines and other explosive devices planted in their farming lands and that they gained a lot of useful knowledge about landmines and such from the awareness workshops conducted by the government. ${ }^{15}$ The successful de-mining programme helped to facilitate progress in the social and economic fields in the war torn areas. It contributed to the country's economy by permitting the cultivation and harvest of agricultural produce in the postwar economy. For instance, when the success of the re-cultivation process is considered in this land mine cleared area, the paddy harvest was almost 63,420 metric tonnes in 2012 (Presidential Task Force for Resettlement - Development, 2013). Completion of mine clearance opened up the whole North-Western coastal belt for fishing, and resulted in a yield of 3,351,750 kg of fresh fish and 372,750 $\mathrm{kg}$ of dried fish in the first quarter of 2011 (Presidential Task Force for Resettlement - Development, 2013). The government resettled more than 500,000 IDPs in all the five districts in the Northern Province and three districts in the Eastern province subsequent to good progress of the mine clearance activities (Presidential Task Force for Resettlement - Development, 2013). Further, the government reconstructed the main roads and rebuilt the railway lines as the mine clearance in the areas was successful. For instance, a $41 \mathrm{~km}$ stretch of the A-32 highway from Mannar to Vellankulam was rehabilitated and another $60 \mathrm{~km}$ were reconstructed along the A-5 and A-12 main roads. After the successful completion of mine clearance, two railway lines were reconstructed, one of $148 \mathrm{~km}$ from Omanthai to Kankesanthurai on the Northern railway and another one of $106 \mathrm{~km}$ from Medawachchiya to Mannar on the Mannar railway line (Presidential Task Force for Resettlement - Development, 2013). Several regional development projects were resumed in former hazardous areas in the Northern and the Eastern provinces. In the East, beautiful beaches were opened up for tourism after completion of mine clearance, thereby providing hundreds of employment opportunities for the local people. (Ministry of Finance and Planning, 2012). Several historical and religious heritage sites were opened to sightseers and devotees. For example, the famous "Madhu Church" in Mannar district in the North ${ }^{16}$ was a totally unsecured area during the war period. In the post-war period the Church area and the access ways were de-mined and opened to the pilgrims. The Church became crowded with pilgrims and the usual religious services are regularly conducted now. ${ }^{17}$ Likewise, Thirukedeeswaram Hindu Temple has been opened to devotees to observe religious rites. As soon as the process of de-mining was completed, both Madhu and Thirukedeeswaram reported 700,000 and 500,000 pilgrims respectively, in 2010 (National Mine Action Committee, 2013). Subine Nandi, UN representative in Sri Lanka, who was satisfied with Sri Lanka's de-mining programme noted that:

\footnotetext{
15 Field Interview with a villager in Nedunkerny on 5 December, 2013, in Nedunkerny.

16 "Madhu Church" is a famous historical religious Centre in Sri Lanka. The area was controlled by the LTTE and in April 2008 the Church premises were liberated by the Sri Lanka Army. It was estimated that thousands of landmines were scattered throughout the Church area. The government successfully removed the land mines in the Church premises. But some forest areas of "Madhu" are still restricted to the people, since the de-mining is still in progress.

17 Field Observation in Madhu Church area in 2014.
} 
Sri Lanka has achieved excellent results in its de-mining programme and the country can complete the de-mining process very soon by continuing with the present institutional setup and machinery (Ministry of Economic Development, 2014).

The significant of the Sri Lanka mine clearance programme is the mine affected victims have been provided a number of emergency assistance programme. These emergency assistance programme is covered by medical care, providing artificial limbs, and psycho-social support. Further the authorities have given more attention for mine affected victims to re-start the livelihood programme. ${ }^{18}$

Therefore, initiatives of the National mine action programme in Sri Lanka carried out by the Sri Lanka Mine Action Committee, greatly facilitated access to more opportunities to the people of the former war-torn areas in the fields of resettlement, social and economic development.

\section{Conclusion}

The above study revealed that the government of Sri Lanka could implement a successful demining programme with help of the Sri Lanka Army and the non-government organizations. It has revealed that $95 \%$ of de-mining works completed, therefore, the government could resettle the majority of IDPs in the areas affected by war. Further, de-mining programme has facilitated initiating building up infrastructures as well as other development projects in the area. Since the mine clearance process showed a continuous progress it also facilitated to re-open a number of religious and cultural places in the country by confirming the social relations between religious groups in the multi-cultural society. Even though, the government de-mining work was performed in the war affected zones, it had benefitted the rest of the country too from some of the initiatives. A successful de-mining programme had facilitated the resettling of displaced persons while other economic initiatives too had been set in motion in the former war zones.

\section{References}

Erin Mooney (2003). 'The Concept of Internal Displacement and the Case for Internally Displaced persons as a Category of Concern'. Refugee Survey Quarterly, 3 (24), 9-25.

Helmick, M. (2000). Humanitarian De-Mining Policy. Pennsylvania: US Army War College.

Kreimer, A., Muscat, R., Elway, A., Arnold, M. (2000). Bosnia-Harzegovina Post Conflict Reconstruction. Washington, D.C.: The World Bank.

Ministry of Economic Development (2012). The National Strategy for Mine Action in Sri Lanka. Colombo: Ministry of Economic Development.

Ministry of Finance and Planning in Sri Lanka (2014). Annual Report 2013 Colombo: Ministry of Planning and Finance.

Presidential Task Force for Resettlement - Development and Security - Northern Province (2013). From Conflict to Stability: Northern Province, Sri Lanka Colombo: Presidential Task force for resettlement - Development and Security - Northern Province.

\footnotetext{
18 “Demining efforts commended”, www.reliefweb.int/report/sri-lanka/demining-efforts-commended (11.06.2019).
} 
National mine action programme in Sri Lanka. Downloaded from: http://www.slmac.gov.lk (26.06.2015).

“Sri Lanka National Mine Action Programme," National Mine Action Committee. Downloaded from: http://www. slnmac.gov.lk (8.07.2014).

Where we Work - Sri Lanka (Danish De-mining Group). Downloaded from: http://www.danishdemininggroup.dk (8.07.2015).

Sri Lanka has achieved excellent results in its de-mining programme. Ministry of Economic Development. Downloaded from: http://www.med.gov.lk (20.06.2015).

De-mining efforts commended. Downloaded from www.reliefweb.int/report/sri-lanka/demining-efforts-commended (11.06.2019). 